\title{
The Concept of Tolerance among Religious Community by the Religious Activists of Interfaith Community and Pantura Belief (Tali Akrap)
}

\author{
Ama Farida Sari ${ }^{1}$, Rusnaini' ${ }^{2}$, Triana Rejekiningsih ${ }^{2}$ \\ ${ }^{1}$ Student of Post Graduate Civic Education Sebelas Maret University, Indonesia \\ ${ }^{2}$ Lecturer of Post Graduate Civic Education Sebelas Maret University, Indonesia \\ amafaridasari@ymail.com
}

\begin{abstract}
Tolerance among religious community is not just an attitude to allow or accept others who differ from our beliefs but also to admit their existence and provide opportunities for other religious community to do everything related to their religious teachings as long as it is in accordance with the limits and does not violate applicable regulations. Tolerance can be strived for both individually and groups through interfaith community such as the Tali Akrap. Tolerance will be maximally carried out if the understanding of the concept of tolerance among religious community is well understood. The influence of religious activists can also influence the attitude of tolerance and acceptance of other different religious. The tolerance among religious community that is implemented well will create a peaceful and harmonious life in the community and maintain the unity and integrity in the national and state environment.

Keywords: Tolerance; Tali Akrap; dialogue.
\end{abstract}

\section{Introduction}

Harmonious life is one of the goals in a society as diverse as in Indonesia. Harmonious means living in harmony among various differences in order to achieve common goals and happiness. In a pluralistic society such as in Indonesia, maintaining diversity is one of the conditions in achieving unity and integrity. Moreover, the diversity in Indonesia includes not only culture but also race, ethnicity, even religion and creeds. The diversity of religious and the mainstream of beliefs is one of the things that can trigger disintegration in society when no efforts are made to harmonize differences. None of the religious or beliefs teaches crime, but when the differences in religious and belief are given no space and boundaries to develop, these differences will trigger divisions and even lead to violent conflict. Aijudin (2017: 119) states that in general violent conflicts and actions that lead to intolerance often occur; (1) individuals or groups deemed heretical and different from the mainstream or majority group; (2) individuals or groups deemed to be blasphemy; (3) individuals or groups considered by society as liberal groups.

Talking about religious phenomena is indeed not a simple problem, because of its multiracial nature, that is as a system, the concept of religion so that it can be sorted into several components, such as (1) religious emotions; (2) belief systems; (3) the system of ritual and ceremonial; (4) the equipment of ritual and ceremonial; and (5) religious community (Daeng, 2000: 310), so that in discussing religious issues and religious differences in addition to real efforts needed to realize harmony it is also important to have an attitude of tolerance among religious community. Tolerance means giving other people the opportunity to do the same for us even though in a different way. Tolerance among religious community means giving equal opportunity for each religion to implement their respective religious teachings and beliefs, worship, implement the religious activities, to implement activities and to develop with agreed rules and limits.

The diversity of religions and streams of belief gives rise to diversity in various elements of religious teaching and the flow of belief itself, starting from the view of one religions to 
another, how to relate to God and fellow human beings in the teachings of certain religions and beliefs to the problem of how the teachings of a religion and the streams of belief becomes easy to be accepted and understood by believer of religion and then make it as a guide. In certain problems the presence of someone who is considered to have more ability and is trusted to lead an activity, a ritual or even believed to convey religious teachings and beliefs is very important. Those who are considered to have more knowledge will convey to the adherents of religions and streams of belief and become role models in choosing or deciding an action related to religion and other people. In other words, religious leaders have a strong enough influence in shaping the mindset of religious people in carrying out religious teachings and dealing with people of different religions, including religious tolerance. On the other hand the influence of religious leaders or leaders can also be used as a means of reducing conflict between religious community in the event of friction or religious problems that threaten the integrity of the nation and state. Therefore it is very important how the views of religious leaders or leaders of a flow of faith in seeing and responding to the diversity of religions and the flow of beliefs that develop in their neighborhoods is even further in the larger context of the Indonesian state. Based on this background, this paper will elaborate on how the concept of tolerance among religious community by religious activists of interfaith community and Pantura beliefs (Tali Akrap) in an effort to create a harmonious life between citizens and between religious communities, especially in the Pantura region.

The benefits gained when the concept of religious tolerance is understood and implemented well, a harmonious life will automatically be realized so that the role of religious leaders or streams of belief are needed in providing examples, guidelines and influence in realizing tolerance among religious community. So in this case the role of the interfaith community is needed in contributing thoughts and efforts in realizing tolerance among religious community. The impact that results when a different concept is collected, discussed together and then harmonized in an understanding and then implemented together in a large community will be far more effective when compared with efforts made individually and separately between groups, because it allows there will still be differences of opinion and interpretation between religious groups so that the efforts made are not optimal.

The efforts made by an interfaith community in realizing tolerance among religious community begin with their views or understanding of tolerance itself. Rosyid (2016: 76) states that literally the word 'tolerant' means to tolerate (respect, allow) the establishment (opinion, views, beliefs, habits, behavior, etc.) of someone who is different or contrary to his own opinion. The word 'tolerance' means attitude or tolerant nature. In line with this opinion, Korobeynikova (2015: 629) also believes that tolerance means not only understanding other people, but also the problem of acceptance, recognition and justification. The way a person describes his attitude towards others forms tolerance itself. Because of these quality, tolerance seems to be a way of understanding others in their changes. Tolerance not only assumes understanding, but also recognition of the existence of those who differ in our beliefs.

Tolerance is not just on the level that we allow others to do something, but more than that tolerance is also about how we acknowledge their existence and provide equal opportunities to do their activities even though they are different from what we do for example such as doing religious activities accordingly with their respective beliefs, carry out spiritual cleansing in accordance with the provisions of their religious groups. Therefore tolerance is not just letting, in tolerance among religious community Casram (2016: 191) states that indicators of society are considered to have tolerated if; (a) consider their own religion true, 
but still provide space for others of different faiths to believe in their religion and beliefs, (b) there is an attitude of letting and not hurting other people or groups both of the same religions and different religions, (c) the existence of personal security, property and minority elements within the community, (d) respect their religion, morality and institutions of different religions, (e) the freedom to embrace religion and implement teachings religious teachings that he believes.

The achievement of tolerance among religious community can be done in various ways, one of which is through religious dialogue activities by interfaith community. Interfaith community is a community that accommodates a variety of different religious groups. Not only different groups, in an interfaith community it is very possible to have different views, so that through dialogue or communication that exists well, the differences that exist have space to achieve mutual understanding. Liliweri (2007: 19) states that one perspective of communication between cultures and even between religions is to emphasize the purpose of communication itself, which is to reduce uncertainty about others. This is why the need for dialogue as religious communication. Communication is needed to find understanding which sometimes becomes a problem in society because of the unwillingness to understand other groups. Furthermore, Liliweri (2011: 257) also states that dialogue as a relationship and communication between religions can be viewed from two dimensions, there are (1) mutual understanding between all parties involved and communicating about the themes, tasks and functions of universal and internal religion (2) the appearance or attraction of values and norms and teachings of religions that can be seen through the behavior of its adherents. Therefore, in order to create harmonious behavior among citizens, it is necessary to have an attitude of Tolerance among religious community and understanding to live in harmony and peace. This harmony can be realized one of them through dialogue or communication among interfaith community.

\section{Research Method}

The method in a research study is a very important part to be considered and influences the analysis and research results. The use of appropriate methods will produce an accurate analysis. The research method of this study is a type of qualitative research using a phenomenological approach and purposive sampling. The data in this study were collected by conducting research directly to the research location with the research subject, the Interfaith Community (Tali Akrap) and supported by relevant literature studies. According to Bungin (2011: 79) in qualitative data collection using observation methods that are generally used from qualitative traditions such as in-depth interviews, participatory observation, or data collection needs to be done by involving several important people for focused discussion. In line with this opinion, Herdiansyah (2012: 116) also states that in qualitative research several data collection methods are commonly used including interviews, observations, documentation studies and focus group discussions. As for the phenomenology approach itself according to Herdiansyah (2012: 66) is one of the qualitative research models developed by European scientist Edmund Husserl in the early 20th century (around the 1935s), where this model is related to a phenomenon. According to Husserl, in every case humans have an understanding and appreciation of each phenomenon they experience and their understanding and appreciation are very influential in their behavior in the future. 
Furthermore, according to Herdiansyah, in the phenomenological approach trying to uncover and study and understand a phenomenon and its unique context experienced by individuals to the level of "belief" of the individual concerned. Thus, in learning and understanding, it must be based on the perspective of paradigms and direct beliefs of the individual concerned as the subject who experiences first-hand experiences. In other words, phenomenological research seeks to search for the psychological meaning of an individual's experience of a phenomenon through in-depth research in the daily life context of the subject under study. Besides that, in understanding and studying a problem, it must be supported by careful and comprehensive preparation from the researcher in order to get full trust from the subject under study, so that closeness can be obtained and can support research.

The use of purposive sampling method itself in this study refers to the opinion of Sugiyono (2009: 85) which states that purposive sampling is a sampling technique with certain considerations. For example, will conduct research on food quality, then the source of the data is a food expert. In qualitative research, the sampling technique used in general is a purposive sampling technique because the researcher chooses the research subject and research location with the aim to study or to understand the main problem under study. Research subjects and research locations chosen by this technique are usually adjusted to the research objectives. In this study the data were taken by interviewing interfaith activist of Tali Akrap community members, field observations with activities that the community did, documentation of field results with supporting documentation from various relevant sources and following focus group discussions (FGD). Data validity test in this research uses data source triangulation technique, which according to Moleong (2006: 330) is done by comparing and checking both the degree of trust of information obtained through time and different ways in qualitative methods carried out by; (1) comparing observational data with interview data; (2) comparing what people say in public with what is said privately; (3) comparing what people say about the research situation with what is said all the time; (4) comparing one's circumstances and perspectives with various opinions and views of others such as ordinary people, people with secondary or higher education, rich people and people in government, (5) comparing the results of interviews with the issue of a related document. So hopefully the results obtained meet similarities or reasons for differences. Data analysis techniques in this study using data analysis techniques from Milles and Huberman consisting of four stages carried out, namely: (a) data collection, (b) Data Reduction, (c) Presentation of data, (d) Withdraw conclusion.

The research is focused on the interfaith community and Pantura belief in Kudus District, with the following considerations; 1) Kudus District has a society consisting of various religions that are recognized in Indonesia and there are many streams of belief so that differences in religious views in accordance with the teachings of each religion must occur; 2) there are still frequent conflicts between religious community even though sometimes they do not appear on the surface but they cause sensitivity among religious community, thus forming an understanding of tolerance that is considered necessary; 3) Tali Akrap community is an interfaith community and belief consisting of various religions and beliefs, in which case the flow of trust is not incorporated in interfaith community formed by the government such as FKUB (Forum for Religious Harmony) so Tali Akrap is a unifying forum between religious community and diverse streams of belief. 


\section{Discussion}

\subsection{Interfaith Community and Pantura Beliefs (Tali Akrap)}

Community or group is a forum that is formed to achieve the desired target or goal together. Through the community, there are also various differences that can be used as a forum to obtain understanding so that what becomes a shared ideal is more easily realized. One of the diversity that exists in society is the diversity of religions and beliefs. As agreed and regulated in the 1945 Constitution the amendment to article 29 paragraph (2) states that "the State guarantees the independence of each population to embrace their respective religions and to worship according to their religion and beliefs". This shows that the diversity of religions is not a mistake or as one of the reasons for the divisions that occur in society because of the diversity of religions that are believed by every citizen guaranteed by the government.

The consequence that will occur with diversity is that citizens need to find ways to maintain such diversity through various activities and attitudes so as to maintain national unity and integrity, in addition the aim is that the community remains harmonious in diversity. One way that can be done is by tolerance among religious community. Tolerance among religious communities means giving every believer or stream of belief the opportunity to carry out their religious activities and provide the same opportunities as what we do to develop and practice their respective beliefs. Tolerance among religious communities can be done both individually and through interfaith community. The existence of an interfaith community is a forum and introduction so that interfaith relations can be more easily established, through the community also differences in religious views will gain understanding. The understanding between religions does not mean eliminating the essence of each different religious teaching, but rather how to understand, accept, provide the same space and opportunity for each religion and belief to develop but with limits and rules to protect, respect, respect and preserve diversity without the existence of an attitude of discrimination, exclusivism or even consider others who are different from them is wrong.

One of the interfaith and religious community in Kudus District is Interfaith Community and the Pantura beliefs (Tali Akrap). Tali Akrap is an interfaith community that has members of various religions and creeds, even a religion that is not yet known to many people, that is Baha'i religion. The existence of Tali Akrap as a unifying container and also creates harmony among religious community both in their environment and wider scope, namely Pantura area. Tali Akrap members are not only limited to the Kudus District area, but also include the Pantura areas such as Jepara, Demak, and Pati. Tali Akrap is a community that was established around 2013 and has a legal body. AHU-0013488.AH.01.07 of 2015, KESBANGPOL Kudus No. 220/561/20/2016 so that the existence of Tali Akrap has been recognized by the government and is moving legally. Tali Akrap was formed as a forum for communication between religious community and also a flow of trust for the wider community. Tali Akrap is different from the interfaith community created by the government, namely FKUB (Forum for Religious Harmony). The difference between FKUB and Tali Akrap in Kudus Regency lies in its members. Members of Tali Akrap itself include all religions and various beliefs, while for FKUB Kudus Regency only includes religions that have been legitimately recognized as a religion, for beliefs to be included in cultural groups and joined by the Tourism Office. This is reinforced by the statement of Mr. Suparno, a Buddhist figure who is a member of Tali Akrap which states; 
"If Tali Akrap is popularized to the grass roots and the meeting of Tali Akrap is not set up, it must be formally so formal. We also adjust the activities to be carried out, conditionally. The FKUB is called a forum from the government, so our activities are always official, the schedule is certain and routine. Because FKUB is a symbol for religious harmony and the FKUB that is recognized and invited in its membership are only religions that are officially or already familiar in society, whereas such a flow of belief is considered a cultural variety so that they engage in activities with the P\&K Office, Tourism and culture ". (Interview on March 2, 2019).

The different characteristics of the community and the diversity of religions and the flow of beliefs that exist within the community allow for barriers, conflicts and also a lack of Tolerance among religious community arising from the interpretation of each religion that is too extreme, the unwillingness of religious communities to relate to other religious communities, even to the conflict of interests of each individual. So that there needs to be an adhesive and unifying differences between religious community carried out not only by one religion but all religions and even the flow of beliefs that exist in society, with this glue, tolerance among religious community can be realized. In line with this thinking, Rozak (2008: 24) states that in overcoming group conflicts, including religious conflicts, do not just rely on the government, but the community must also improve and intensify communication between existing religious communities by developing an attitude of openness, democracy, tolerance and peace.

Then the presence of an interfaith community that can accommodate various religions and streams of belief is expected to provide benefits for its members even for the wider community, especially in realizing a conducive climate, a harmonious life for the unity and integrity of the nation.

\subsection{The Concept of Tolerance among Religious Community According to Tali Akrap Activists}

The concept is a description of part or whole that is used to explain things become clearer. The concept is usually based on the knowledge and understanding possessed by someone who comes from experience or events either directly or indirectly experienced by the person concerned. This understanding and knowledge possessed by someone is believed and used as their guide in doing various things, including in behaving towards other people and different religions. If their understanding is correct, then the attitude shown will be right, but if their understanding is wrong, then their attitude will instead improve relations between communities but create a barrier to division.

Tolerance among religious community who are well understood will make every religious adherent aware of continuing to do good and better, both not only shown with respect but also to the level of harmony, accepting differences and also seeking harmony in order to stay awake. The concept of tolerance among religious community must be understood by every adherent of the religion and also the flow of belief. In addition to influencing the attitude that will be shown to others, understanding the concept of tolerance among religious community also shows the extent of one's understanding when applying it in the face of conflict, respect, and respect for other religions that are around. The concept of tolerance possessed by religious leaders, will also affect the members or adherents of the religion he leads, so if religious leaders can build tolerance with the right concept and can also use the concept of tolerance for the common good, directing the adherents of their religion others act according to what he directs 
in goodness, then harmony in society will definitely be achieved. But on the contrary, if religious leaders cannot understand the differences well, do not have an attitude of tolerance and it is all followed by members of the religion he leads, it will instead create a barrier or separation between religious groups.

Interfaith activists in Tali Akrap understand very well that tolerance is very important to maintain unity and integrity, reduce conflict, provide a correct understanding of mutual respect, respect, and accept other religions and beliefs that are not in line with them. Through this Tali Akrap community all kinds of differences are explained, explained and communicated well so that it is not intended to change what is different into the same but to harmonize differences so there are no misunderstandings, correcting stigmas that may be mistaken and developing in the community and among members people of different religions can respect, respect, accept and acknowledge the existence of those who are of different faiths from us. The importance of understanding the concept of proper tolerance among religious community in line with the opinion of all interfaith Tali Akrap activists, where Tali Akrap itself is aware that tolerance is very important to safeguard this diverse society. The following is an illustration of the concept of tolerance among religious community according to each interfaith activist of Tali Akrap presented in table form;

Table 1. The Concept of Tolerance among Religious Community According to Tali Akrap Activists

\begin{tabular}{|c|c|c|c|}
\hline No. & $\begin{array}{l}\text { Informant's } \\
\text { Name }\end{array}$ & Agama & The Concept of Tolerance \\
\hline 1 & Thomas & Katholik & $\begin{array}{l}\text { The concept of tolerance among religious community } \\
\text { in Catholic religion teachings is that not all people } \\
\text { must be Catholic. In Catholic teaching, Catholicism } \\
\text { does not monopolize heaven. So heaven is not just for } \\
\text { Catholics. But anyone who does good according to the } \\
\text { will of Allah is the one who enters heaven, including } \\
\text { when we respect other religions, as one of the } \\
\text { following verses says "I am the God of your Allah, } \\
\text { Love me above all else and love your fellow as you } \\
\text { love yourself". So what is meant by fellow is not only } \\
\text { fellow religions but also fellow humans of different } \\
\text { religions }\end{array}$ \\
\hline 2 & Hani'ah & Islam & $\begin{array}{l}\text { As Muslims it is the teachings of the Prophet that } \\
\text { Tolerance among religious community is mutual } \\
\text { respect, mutual respect between different religions to } \\
\text { maintain togetherness. if it's a matter of confidence, } \\
\text { surely we already have each other's beliefs }\end{array}$ \\
\hline 3 & Widodo & Konghucu & $\begin{array}{l}\text { Tolerance is accepting others, respecting and } \\
\text { appreciating even though they are different from us. } \\
\text { We do not feel the most righteous and think that what } \\
\text { is different from us is wrong. }\end{array}$ \\
\hline 4 & Budi Santoso & $\begin{array}{l}\text { Sedulur } \\
\text { Sikep }\end{array}$ & $\begin{array}{l}\text { Tolerance is that we respect each other, we respect } \\
\text { each other based on existing recognition. The }\end{array}$ \\
\hline
\end{tabular}


connection with what I do is a choice because I feel right. If the religious problem becomes our choice, but if it is in accordance with our position as humans, then we are all human beings, we are all siblings whatever your religion. Whatever you believe, we must have a religion, but we must believe that what is important is harmony, mutual respect and respect.

\begin{tabular}{llll}
\hline 5 & Setiawan & Kristen & $\begin{array}{l}\text { Brotherhood, mutual respect, accept differences. Your } \\
\text { religion is your religion, and my religion is my } \\
\text { religion. Christians must love all people, that means } \\
\end{array}$ \\
& & $\begin{array}{l}\text { all religions, without limits even though your enemies } \\
\text { love each other. }\end{array}$ \\
\hline $\mathbf{6}$ & $\begin{array}{l}\text { Rosyid } \\
\text { (Tali Akrap }\end{array}$ & Islam & $\begin{array}{l}\text { The meaning is that if every community has religions, } \\
\text { Leader) }\end{array}$ \\
& & $\begin{array}{l}\text { both the same religion and a different religion realizes } \\
\text { that there are differences, especially differences in } \\
\text { religion, by understanding that conflict will not occur. }\end{array}$ \\
& &
\end{tabular}

7 Putu Dantre Hindu Tolerance is togetherness, mutual understanding between other religious community, meaning that we can also adjust the environment. What culture around that we accept. Not all of our culture does, but we adjust it to the rules, meaning that all the activities we carry out do not conflict with the prevailing customs in which we live. We do not interfere with each other and we must be able to respect others.

\begin{tabular}{lll}
\hline 8 Suparno & Budha & Tolerance among religious community teges e \\
& sesrawungan (mingling) life, and with other beliefs \\
& can adjust. So we know that we are brothers, know that \\
& we are not the same and the differences are certain, so \\
& we know that we are different, so we must be able to \\
& adjust to accept those differences. For example it's like \\
& our fingers, these five are all different and work \\
& according to their individual needs. If for example this \\
& finger is all the thumbs, it's not right, and that's all let \\
& it play a role and complement each other, adjusting to \\
& differences \\
\hline Sulistiyani & The teachings of the Baha'ullah state that "O dear \\
& friends! The camp was upheld; thou shalt not regard \\
& one another as strangers. You are the fruits of one tree \\
& and the leaves of one branch. Be loving to one another \\
& with love and harmony, with friendship and \\
& brotherhood. So strong is the light, so that it can \\
& illuminate the whole world "so that we are obliged to \\
& respect and assume that those who are different from \\
& us are a family of humankind \\
\hline
\end{tabular}


Tolerance among religious community understood by Tali Akrap activists provides space and enlightenment for Tali Akrap members themselves and those around their environment, that tolerance does not just leave others alone, tolerance is not only limited to members of the community they follow, but tolerance is for all members of the community, both of the same religion and different religions, both like-minded and with different opinions. Because the purpose of tolerance is an effort to create a harmonious, safe, peaceful life even in differences.

\subsection{Tolerance among Religious Community through Interfaith Dialogue}

Tolerance that shows our openness towards other people who are different from us can be done in various forms and activities. Tolerance which is interpreted by interfaith activist by Tali Akrap in general is an open attitude towards others, accepting their existence and providing equal opportunities for others to do the same as what we do manifested in various activities both internal and interreligious and external. With those who cooperate with the government. The activities carried out by Tali Akrap in realizing tolerance among religious community are packaged in the form of interfaith dialogue activities.

Interfaith dialogue is not only social communication but also intercultural communication. Dialogue as a form of interfaith communication according to Liliweri (2011: 257) can be viewed from two dimensions there are; (1) mutual understanding between all parties involved and communicating on the theme of the universal and internal duties and functions of religion and (2) the appearance or attraction of values and norms and teachings of religions that can be seen through the behavior of its adherents. Dialogue is carried out not only for meaningless communication but also for the purpose of conveying each difference to find unidirectional understanding or it can also be used as an insight and idea about a knowledge to avoid misunderstanding between religious community. This is in line with the opinion expressed by Zheltukhina, M.et. al (2016: 7409) which states that communication, dialogue is something that is very important for humans, with communication we can convey the goals we want to achieve.

Structurally, functional society is formed on the basis of an agreement between its members that can overcome differences so that it can be seen as a system that is functionally integrated in a continuity that is a tolerant society. Interreligious dialogue conducted by Tali Akrap is carried out with a relaxed discussion and harmonizing the various differences that exist between each religious group. The model of this dialogue is in accordance with the statement of Mr. Setiawan, a Christian religious activists who is a member of Tali Akrap as follows;

"The model is usually that later it will introduce the creed or teachings of their respective religions but may not influence, may not invite and also should not be refuted" (Interview on 28 February 2019).

But this activity in realizing the tolerance among religious community is not only carried out in the form of dialogue, but also activities such as the social service of church youth for underprivileged communities, counseling from the police station about the dangers of drugs and also other government programs that do need to be socialized to form awareness citizens too. So that the purpose of Tali Akrap community is not only to understand, accept and provide opportunities but also to make a good country citizen who loves and is also proud of his nation and country. This goal is also in line with the statement made by Mr. Rosyid as the leader of Tali Akrap as follows; 
"Tali Akrap activity is not only dialogue, but we also have cooperation with government agencies and others, the aim is to better the citizens' knowledge. Usually we introduce with understand the products of legislation, for example, when we were in Rahtawu, the socialization of tax amnesty, e-ID card at Vihara Colo, with Holy Police regarding drug laws. In the house of Mrs. Haniah (Former Deputy District Head of Kudus) also discussed about national security, we invited the Kudus District national land agency to understand how the electoral process for our new voters was also in collaboration with the Kudus District KPU ". (Interview on February 26, 2019).

Dialogue activities and various other social activities carried out by Tali Akrap community have one goal that is harmony, tolerance, understanding and acceptance of the whole society even though they have different beliefs. Tolerance will be created when different societies have an understanding to maintain harmony, maintain national unity and integrity. We realize as citizens that our position is equal, our rights are equal and the obligation to safeguard the integrity of a diverse nation, religion, race, and differences between these groups is also a shared duty and obligation.

\section{Conclusion}

Tolerance among religious community is understood by allowing, accepting, and providing equal opportunities for others who are different from us to carry out all activities both social and religious as long as it is in accordance with the provisions and limits that have been regulated by law and agreed upon. Tolerance provides space and opportunity for various religions and streams of beliefs to get an equal position among citizens. With the tolerance of harmonious community life will be created, with the tolerance of national and state integrity will be maintained. Tolerance can be realized and carried out in various ways, one of which is interreligious dialogue, dialogue can create an understanding between religious community to avoid misunderstandings, conflicts or even divisions between religious communities. With dialogue it is hoped that a better life order among religious community will be created.

\section{References}

Aijudin, A. (2017). Mengelola Pluralisme Melalui Dialog Antar Agama (Sebuah Tinjauan Teoritik). Jurnal SMaRT Studi Masyarakat, Religi dan Tradisi, 119-124

Bungin, B. (2011). Penelitian kualitatif: Komunikasi, Ekonomi, Kebijakan Publik, dan Ilmu Sosial Lainnya. Jakarta: Kencana Prenada Media Group

Casram. (2016). Membangun Sikap Toleransi Beragama dalam Masyarakat Plural. Wawasan: Jurnal Ilmia Agama dan Sosial Budaya, 187-198

Daeng, H., J. (2000). Manusia, Kebudayaan dan Lingkungan. Yogyakarta: Pustaka Pelajar Offset

Herdiansyah, H. (2012). Metodologi Penelitian Kualitatif untuk Ilmu-ilmu Sosial. Jakarta: Salemba Humanika

Korobeynikova. (2015). Tolerance in the Context of Soft Globalization. Procedia - Social and Behavioral Sciences, $626-630$

Lexy, M. (2006). Metodologi Penelitian Kualitatif. Bandung: PT. Remaja Rosdakarya Offset 
Liliweri, A. (2007). Dasar-Dasar Komunikasi Antar Budaya. Yogyakarta: Pustaka Pelajar Offset . (2011). Gatra-Gatra Komunikasi Antarbudaya. Yogyakarta: Pustaka Pelajar Rosyid, M. (2016). Esai-Esai Toleransi. Yogyakarta: Tim Idea Press

Rozak, A. (2008). Komunikasi Lintas Agama: Modal Sosial Pembentukan Masyarakat Sipil. Jurnal Dakwah, Januari-Juni 2008

Undang-Undang Dasar 1945 Amandemen

Zheltukhinaa, M., et. al. (2016). Dialogue as a Constituent Resource for Dramatic Discourse: Language, Person and Culture. International Journal Of Environmental \& Science Education, 7408-7420. 